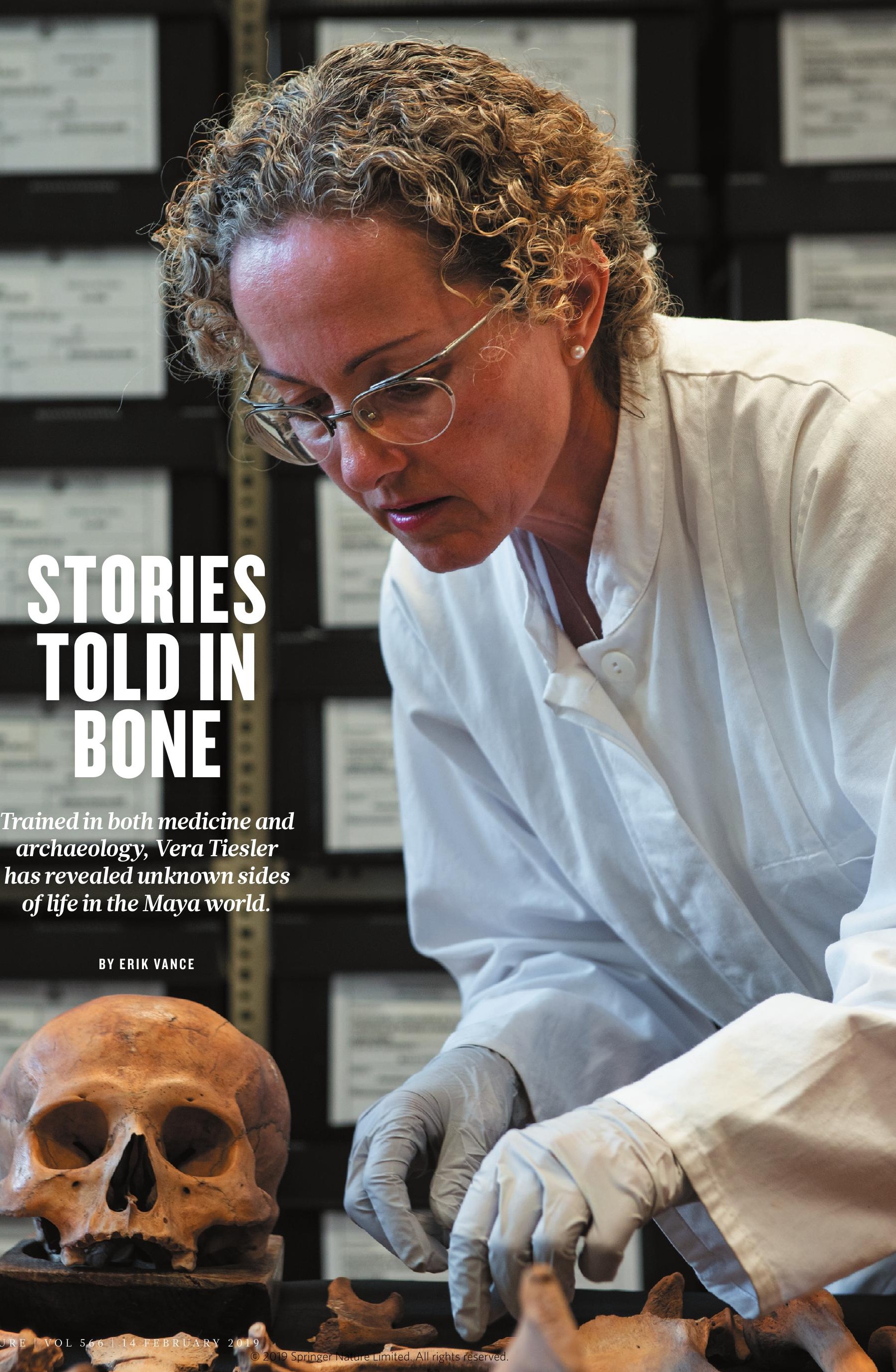


$\mathrm{T}$ he Autonomous University of the Yucatán, in the Mexican city of Mérida, holds one of the most comprehensive libraries on Earth. But few books line the shelves on the bottom floor of the anthropological sciences building. Instead, boxes are stacked from floor to ceiling in almost every corner of the laboratory, with labels naming Calakmul, Pomuch or Xcambo and other ancient Maya ruins. Inside every box is a set of human bones.

Bodies from some 2,000 burials are stored here, with another 10,000 records of others in a database. The remains of some of the most famous Maya kings have passed through this room at the university. Ancient paupers, warriors, priests, scribes, lords, ladies and artisans - the lab has seen them all.

And tucked in the middle of it, surrounded on all sides by the remains of long-dead civilizations, sits bioarchaeologist Vera Tiesler. Over the past quarter of a century, Tiesler has carved out a reputation as the world's premier specialist on ancient Maya remains, which has helped her to unlock secrets of their lives and culture. On a drizzly November day, she pulls out one of her favourite bones, a flat strip no bigger than her finger, and puts it under a magnifying lens. It's a sternum bone from a young man who was probably sacrificed. She points to a deep V-shaped cut over the centre of the chest, and she marvels at the skill of the person who inflicted it.

"You'd need a lot of strength - a lot of force - and you'd need to know exactly where to hit," she says. "Because if not, you'd have these false starts, it would be a mess."

Trained as a physician and an archaeologist, Tiesler reads the region's history in its bones. By bringing a medical eye to ancient Maya civilization, she has changed how scientists perceive that society, putting some of its seemingly more unusual traditions into context and shedding light on the lives of key individuals.

Through studies of thousands of bodies, she has helped to illuminate how the Maya's knowledge of human physiology was an integral part of their society - from birth to death. How they shaped the heads of their babies reveals insights into their family traditions and spirituality. And her investigations into many of the deaths suggests that ritualized sacrifice was perfected to a high art - an idea that challenges popular views of the Maya world as a society of peaceful stargazers. Throughout, she has uncovered a rich culture in which the human body was deeply woven into religion, tradition and politics.

"I always look at things from a different angle," Tiesler says. "That way it never loses its attraction. It's like it triggers me. I find it thrilling."

Tiesler is an anomaly in Mexican archaeology. Born in Germany and trained in Mexico, where she has lived for decades, she has crossed cultures to make partnerships and discoveries around one of the most famous ancient civilizations.

"There are very few people with those kinds of credentials," says Stephen Houston, an archaeologist at Brown University in Providence, Rhode Island. "She represents this collegial internationalism - a kind of global approach to knowledge in which people at their best, in the best conditions, work together."

\section{THE POWER OF LOVE}

Quiet and bookish as a child, Tiesler had always felt out of place in the small German village near the border with France where she grew up. She just saw things differently. Although her friends went to James Bond films to see the hero, she was more interested in his steel-toothed nemesis Jaws. And she yearned to travel.

So she enrolled at Tulane University in New Orleans, Louisiana, where she avoided its famously boisterous campus life and graduated after just one year, with honours, at 19 in 1985. Afterwards, she took a little money that she had won in an art competition and flew to Mexico City for two weeks before returning to Germany to start a medical

Vera Tiesler examines the remains of a person buried in Mexico during early colonial times. degree. In Mexico, she met a young doctor and archaeology enthusiast, who offered to take her to the ruins of Teotihuacán just outside the city with his friends. They fell in love, and spent a week driving thousands of kilometres through the Maya region to visit sites - although she neglected to inform her parents, who eventually called Interpol in a panic.

"I saw Mexico in a way that I fell in love with," she says.

They made plans to get married, but her fiancé died suddenly in 1987 while Tiesler was in Germany studying medicine. She vowed to go to Mexico and do what he always wished he could - become an archaeologist. Against the wishes of her family, she enrolled at the National Polytechnic Institute in Mexico City and has lived in Mexico ever since.

Tiesler finished her medical degree in Mexico and later earned her doctorate in anthropology from the National Autonomous University of Mexico (UNAM) in Mexico City. Back then, few people were interested in the bones of the ancient Maya; Mexican archaeology was about temples, pottery and jade masks. Those who did study bones typically collected only the most basic information.

"They figured they had done everything they could. They had measured them, they had classified them," says Manuel Gándara, an archaeologist who oversaw her work at the time, and is now at the National School of Conservation, Restoration and Museography in Mexico City. "And here comes this lady saying, 'Oh but we haven't taken samples of tissue to analyse".

Tiesler was introducing a field often called taphonomy, which was gaining popularity in Europe at the time, and goes beyond classifying bones by trying to reconstruct the body that once hung from them. But the practice had never been applied to ancient Mesoamericans. She began looking through Mexican museums at various collections of skulls, which she considered the most interesting parts of the body. She became fascinated with the practice of head shaping, whereby a mother tied boards to an infant's head to shape its growth.

It didn't hurt the baby and was a surprisingly common practice around the world. Archaeologists who study the Maya assumed that the practice had something to do with religion, but knew little more than that.

Tiesler noticed that certain regions tended to have specific head styles. After looking at a few hundred skulls, she found that people during the Classic period (250-900) along the coast of today's Veracruz had a vertical, pear-shaped style, those in the lowlands had a sloping, tubular style, and those along the coast of the Caribbean Sea had wide, flat heads. Over time, that shape became popular, and dominated the late Classic period ${ }^{1}$.

By looking at drawings and carvings from the time and comparing them to skull shapes, she deduced that head styles follow matrilineal traditions: children tend to have the mother's style. She, along with others, found a possible reason, based on Maya traditions in colonial times. The ancient Maya saw babies as not-yet human, and at risk of losing their essence through a few points in their skulls, she says. By shaping the head, the Maya kept the essence in place $^{2}$.

\section{LIVES OF THE KINGS}

By the time Tiesler got her PhD in 1999, she was already fleshing out much of ancient Maya culture and soon began excavating royal tombs. The ancient Maya spanned from the northern Yucatán peninsula southwards towards modern-day Honduras (an area about the size of today's Egypt), and Tiesler has examined many of its important kings or queens found over the past 100 years. She was part of the team that examined Pakal the Great (or K'inich Janaab' Pakal) of Palenque and his companion, the Red Queen, between 1999 and 2006. She found that their relatively luxurious lifestyle gave them premature osteoporosis, visible in their thinning bones. Their teeth were barely worn from eating soft, decadent food their whole lives ${ }^{3}$.

Tiesler excavated the bones of a king named Lord of the Four Sides of the Flint (or Ukit Kan Le'k Tok) of Ek Balam, depicted in a painting in his opulent vault with a double lip. She found that he had a disfigured upper jaw with teeth that were dislodged and had then healed at angles, possibly from a blow to the face during battle, given that he was eager to show it off.

Tiesler's favourite kings are the ones for which she oversaw the excavation process from start to finish. Take Fiery Claw (or Yukom Yichak K'ahk') of the Classic Snake dynasty. The Snakes were a line of kings who moved into the Maya world in 560 and, over 150 years, built the closest thing the Maya ever saw to an empire.

The first of these, Sky Witness, was found in a moderately humble 
grave, shared with a handful of other elite warriors who died in battle. Tiesler had very little time to inspect him, but found his skull speckled with deep injuries - some on top of previously healed ones. His shield arm was mangled from numerous heavy blows, and he could barely have used it by the time he died, in his early 30 s. All this fits the image in snippets of writing from across the region that describe a brilliant military leader who toppled the ruling city of Tikal and establish the Snakes as the dominant force in the region.

Contrast that with Fiery Claw, who came at the end of the Snakes' dominance in the region. When Tiesler and other researchers excavated the king, they found him opulently arrayed in a chamber with a jade mask alongside a young woman and a child sacrificed at the same time. From her studies of his bones, Tiesler found that he was portly, bordering on obese, and in his 50s when he died. Like Pakal, his teeth showed that he spent his life eating soft food such as tamales and sipping a chocolate and honey drink popular among the elites ${ }^{4}$. One carving shows him as a fit man, athletically playing a Mesoamerican ball game. But Tiesler found that Fiery Claw had a painful disease that fused several vertebrae together, meaning the game would have been dangerous to play, and suggesting that the carving was propaganda.

\section{SACRIFICE AS SPECTACLE}

These kinds of details do not change the basic plot line of Maya history, but they do fill out its characters and hint at what their lives were like.

Since 2000, when Tiesler became a professor at the Autonomous University of Yucatán, she has established herself as the premier bioarchaeologist in Mexico. Her lab has compiled a database of 12,000 burials, 6,600 of which she and her colleagues worked on directly. Her university alone houses the remains of more than 2,000 individuals from ancient, colonial and modern times, most of which she had a hand in uncovering.

Tiesler enjoys a unique position in Mexican academia. After centuries of watching antiquities fly north, along with all the credit, the authorities have become reticent to allow foreign archaeologists to do large projects in the Maya area. But Tiesler readily works with specialists in the United States, Europe and Mexico and publishes widely in both English and Spanish.

She pairs this multiculturalism with a ravenous appetite for research and boundless energy. This came in helpful when she dug into her favourite topic: human sacrifice.

In 2003, while working in Champotón, on the coast of the Gulf of Mexico, three of her students discovered a group of bodies that seem to have been discarded. When Tiesler examined the bones, she found a sternum with deep, clean cut marks in it that showed intentional, almost surgical, placement. The cuts were horizontal, not likely to have come from battle, and were later found in the same place on other bodies.

Tiesler's mind went back to her medical training. A skilled person, who knew what they were doing and was moving fast, might have cut the chest open, pulled the ribs apart and exposed the heart while the victim was still alive. "Then the heart would come out by itself and would be jumping," she says.

To Tiesler, these cuts represented something larger than just macabre murder. It was more likely to be a spectacle, some form of ceremony. Her observations resonated with some written accounts of Mexica (or Aztec) sacrifice 1,300 kilometres away, from around the time of the Spanish invasion in the sixteenth century. This led her down a fascinating and dark rabbit hole into the physiology of human sacrifice. How was it done? And why?

She and her colleagues started noting cut marks in other remains that seemed too precisely placed to be accidents. As she compiled them and compared them to iconography, she began seeing similar well-placed cut marks in other bones that looked to her like signs of elaborate rites.

Carvings at places such as the Maya ruins Chichén Itzá show captives being beheaded in front of crowds. If you cut the head off seconds before removing the heart, the organ will keep pumping as you hold it, says Tiesler. Do it the other way round and you can feed the heart to its owner, a practice also hinted at in texts. A different procedure, which leaves cut marks on other parts of the chest, might create a tranquil pool of blood in a victim's chest cavity that looks almost like a lake.

Tiesler's ideas are not universally accepted - some people see the killings as less choreographed - but Tiesler says they fit with the Maya world view. As she sits at her desk, a nook in the centre of her laboratory surrounded by 3-metre-high stacks of bone boxes, she is not revulsed by this practice. She is fascinated. These executions required practice and precision - perhaps taking generations to perfect - and must have carried profound meaning.

She says that the method of sacrifice was incredibly important. In that moment, the victim becomes a sort of pretender god - a glimpse of the divine in human form, an idea that was well-documented among the Mexica people. Thus, the executioners were not feeding a person's heart to himself, but rather to a god.

Tiesler is not the first to propose these ideas. Sacrifice leading to divinity (either in the executioner or in the victim) is well-documented in other cultures of the Americas. But her work supports ideas of religion gleaned from what other sources describe as a Xipe Totec sect, named after an Mexica god said to wear human skins over his own.

During the Post-Classic period (950 to 1539) the Maya people practised a great deal of human sacrifice and body processing, she says, including creating racks of skulls called tzompantlis and cutting off human skins to wear over the body.

As grisly as these killings might seem, they were nothing compared with other practices at the time. Far worse to Tiesler was the European use of the breaking wheel, a device that allowed torturers to break a criminal's bones, one by one, before displaying the victim to the village.

Still, her descriptions of sacrifice do not sit well with everyone. Anthropologists once depicted the Maya as a purely peaceful civilization and, although that view has largely gone, many loathe casting them in such a bloodthirsty light.

The history of archaeology is filled with warped ideas of ancient cultures that have been promulgated by scholars from powerful nations, and modern researchers tread carefully into issues such as sacrifice and cannibalism. "It has been an argument by colonizers to depict people of other societies in what we'd consider the worst imaginable scenarios," says Estella Weiss-Krejci at the Institute for Oriental and European Archaeology of the Austrian Academy of Sciences in Vienna. "You

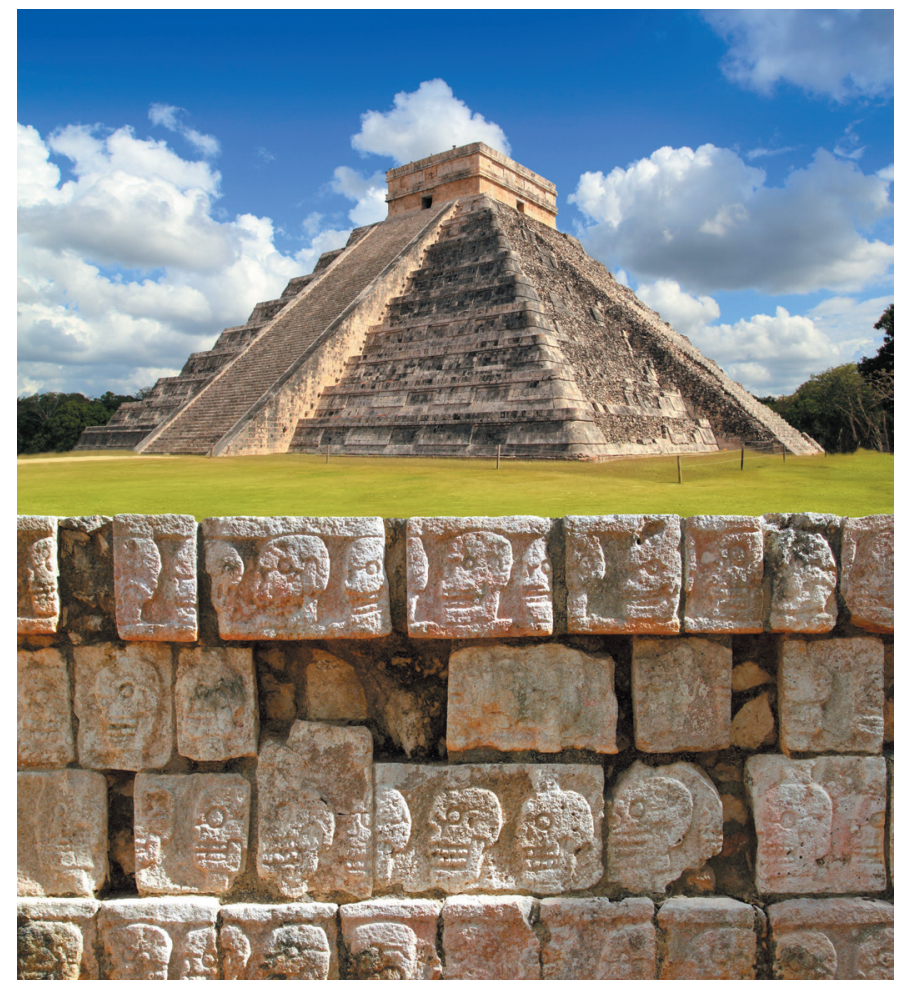

An elongated skull from the Classic Maya Period reveals clues about the tradition of shaping infants' heads to alter their growth. 


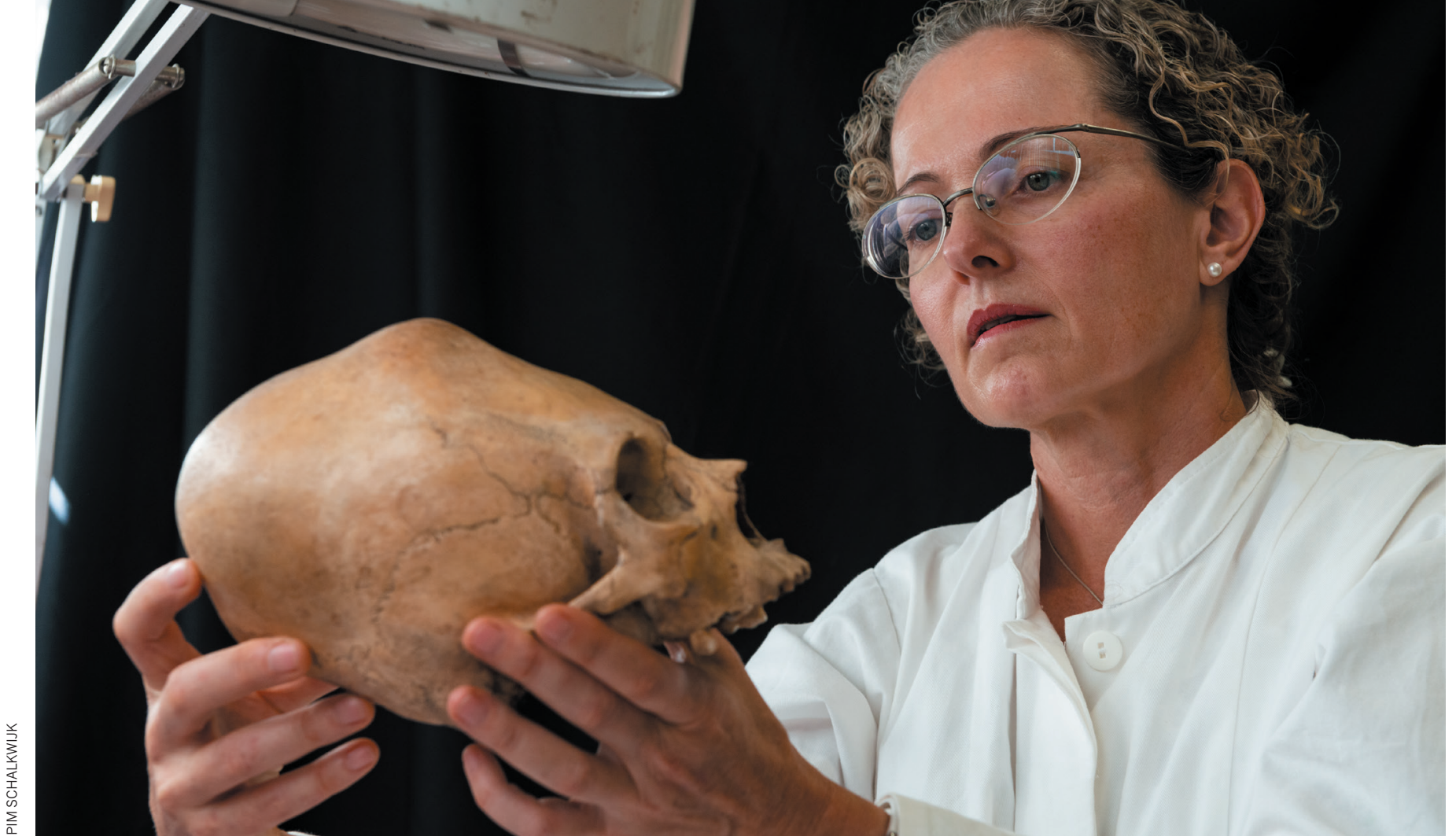

An elongated skull from the Classic Maya Period reveals clues about the tradition of shaping infants' heads to alter their growth.

always have to think of all the possibilities, especially when you're not sure what happened."

Weiss-Krejci thinks that human sacrifice was incredibly rare in the Maya world and that the woman in Fiery Claw's burial was actually a family member who died later. If the sacrifices that Tiesler describes were so common, Weiss-Krejci wonders why there aren't hundreds of chest bones with the same cuts. She thinks that sacrifices were relatively rare and diverse, with little repetition. Tiesler responds by pointing to numerous examples from her extensive database of burials, but she says that given the amount of post-mortem mutilation and the wet soils, we are lucky even to have those.

The two respect each other, but Tiesler says that Weiss-Krejci follows a well-meaning, although misguided, trope. She says that local Maya are not turned off by the gruesome reality of their forebears, any more than are the descendants of ferocious Romans or Vikings. Understanding another culture means looking at their history, warts and all.

"If we don't understand, we can believe they are crazy or they are different from us. But they are not different. We are all the same," says Kadwin Pérez, a Maya PhD student in Tiesler's lab who grew up with Mayan spoken around the house.

\section{DISEMBODIED HEADS}

Walking through an ancient Maya site with Tiesler is a little like getting a backstage pass to a magic show; everything you thought you understood before starts to look different. That was the feeling on a trip last November through Chichén Itzá. Just past the iconic El Castillo, the step pyramid, is the site's famous tzompantli, a stone platform decorated with carvings of hundreds of skulls and various half-dead underworld monsters.

Tzompantlis were skull racks constructed as a series of horizontal beams stacked vertically, like a ladder. Adorned with skulls, they were popular with the Mexica. Many experts have assumed that Maya images of tzompantli are metaphorical, and do not refer to an actual event. Some go so far as to say that the Maya did not participate in the practice.

Tiesler stops and examines the carvings. Colonial Spanish drawings of tzompantlis often depict them with clean, white skulls. She squints. They're not clean skulls at all, she says, but heads that have been recently cut off and still have flesh attached. The sculptor even included cheeks and eyeballs on many of them, whereas others seem more decayed. In addition, the head shapes vary wildly, suggesting that most were foreigners, perhaps captured on the field of battle. It was not, as some have suggested, an honour to be sacrificed. It's a classic example of Tiesler's work, putting flesh back on the bones.

Chichén Itzá has been studied by countless specialists and is visited by more than two million people a year - every detail of its structures has been mapped, analysed and discussed - and yet no one thought about these carved heads as a medical doctor would until Tiesler.

Later, we sit down in a small hut to eat a traditional corn-based pie, stuffed with chicken and spices and cooked underground, and a hot chocolate drink that has changed little since kings sipped it 2,000 years ago. Tiesler has been partnering with a local university trying to promote ecotourism that benefits local communities. Maria Guadalupe Balam Canche, who made the dish as a part of the month-long Day of the Dead festivities, says she doesn't feel a direct connection to the builders of the nearby pyramids that draw the tourists. It's a common sentiment here. They were the old Maya - alien, distant and perhaps a little brutal.

Tiesler sees things differently. As she slices off a portion of pie, she notes that eating meat cooked in the soil has echoes of ancient ideas of the underworld. People here commonly remove family members' bones and clean them, much as Fiery Claw once did. And during rodeos here, it's not uncommon to pull the heart from a dying calf as part of the show.

Centuries of Spanish and Mexican statehood have influenced the culture here, but they haven't changed the bones. Tiesler, who also works with more modern burials, sees a long arc of history in a way that few people can. In her bone library, she can see the rise and fall of empires, the wax and wane of famine and disease and the tales of many, many lives.

When Europeans came to these shores, their priests burned the Maya writings and their diseases swept through the population. Almost all of what the people who built these pyramids wrote down was lost, their libraries destroyed. It's a hole that archaeologists have endeavoured to fill. And although we will never rebuild their lost libraries, at least one woman hopes to paint a picture of how these people lived by using the only libraries left for us to peruse.

\section{Erik Vance is a science journalist in Baltimore, Maryland.}

1. Tiesler, V. The Bioarchaeology of Artificial Cranial Modifications: New Approaches to Head Shaping and its Meanings in Pre-Columbian Mesoamerica and Beyond Chapter 10, 239-256 (Springer, 2014).

2. Tiesler, V. Child. Past 4, 117-132 (2011).

3. Tiesler, V. \& Cucina, A. (eds) Janaab' Pakal of Palenque: Reconstructing the Life and Death of a Maya Ruler (Univ. Arizona Press, 2006).

4. Tiesler, V., Cucina, A., Stanton, T. W. \& Freidel, D. A. Before Kukulkán: Bioarchaeology of Maya Life, Death, and Identity at Classic Period Yaxuná (Univ. Arizona Press, 2017). 